\title{
Defining Edges: Toward a Social Poetics of Housing
}

\author{
M. JANA PEREAU \\ Washington University \\ USA
}

\section{INTRODUCTION}

The house, as a formal and functional type, also provides a basic container for culture and for meaning. Its form will not be altered casually, and when people do undertake to change their houses, those changes will undoubtedly signify other changes in their cultural and social world. Along the U.S./ Mexico border, the unique political geography of the borderlands allows people to build their own housing on a broad scale - in other words, to build vernacular housing. This building takes place in colonias - outside the constraints of urban zoning and building codes - by a largely Latino and immigrant population.

While the borderland sustains a confluence of cultures, many of the old traditions do not survive the journey northward, and the colonia residents must necessarily find ways to preserve their most important values and customs while embracing the ways of their new homeland. Their houses - with their solid masonry walls, their simple, sturdy shapes, classical symmetry and characteristic landscape reveal the complexity of this new cultural stream. These raw, but vital, communities offer a "living laboratory" in which to study housing types and the deeply rooted social and cultural realities that produce them - the social poetics of housing. My study of the colonias has convinced me that the process of cultural adaptation that operates in the borderlands speaks to the issues of change and the problem of collective identity that characterize - not just the colonias but to the larger, mobile and ever-changing society as well.

\section{DEFINING A SOCIAL POETICS}

The etymology of "poetic" goes back to the Greek word meaning "to make, to create, to heap up." Thus poetics begins as simple making, and we are familiar with this idea when used in reference to construction, to craft and to design. But especially in reference to architecture, the more inclusive meaning of poetics necessarily extends to the collective act of creating a social world, the social construction of reality to use Berger's term. I approach this subject from the anthropological perspective, wherein everyday objects and actions provide the sources for the interpretation of cultural

meaning systems. Anthropological insights seem to me to have great relevance to the study and practice of architecture, but have been largely overlooked in recent theoretical and pedagogical discussions.

The anthropologist Mary Douglas describes the way commonplace everyday things are treated as so self-evident that they require no justification. Such information becomes 'backgrounded' when they are "...regarded as too true to warrant discussion." 2 It is important to reiterate that these basic understandings, these things "too true" to discuss, rest at the heart of socially constructed meaning. And we find this king of backgrounding especially prevalent in regard to houses whose unremarkable shapes serve as the unexamined background for the dailiness of our lives.

The term poetics in the sense of making, does not exclude judgments concerning the beautiful, the good and the true all of which intersect with ethical judgments on the very nature of reality: the proper form of a house which in turn defines the correct way to live. Such assumptions nevertheless undergo constant revision and change, and, as the anthropologist Michael Herzfeld notes, "The very distinction between moral and aesthetic values blurs: both are negotiated through social performance; both project 'eternal verities' in which consistent form masks uncertainty."

As used by linguists, "poetic" refers to any device that cues the author's intention to set this object or that performance apart from the ordinary. This removes it from the everyday and demands a closer look, more particular and perhaps more critical attention. Thus poetics, as creative activity and as critical observation, provide the means by which people step outside their particular situation and then imagine and invent alternatives. Obviously this process forms one of the important means by which architects create innovative designs, but it also describes the means by which ordinary people negotiate, through poetic manipulation and critical evaluation, the most appropriate forms for their houses.

\section{POETICS AS A MEDIUM OF EXCHANGE - AND CHANGE}

Poetics, then, engages both tradition and innovation to create a kind of dialectic tension. In the case of the colonias, these 
tensions and contradictions are clear. The contrasts between Mexico and the United States create a border situation that perhaps has no parallel in the world: 2,000 miles of confrontation between the wealth and power of the U.S. set against the poverty and aspirations of Mexico. Immigration entails a kind of "cultural revolution" for the migrants: attitudes, habits, language, clothing, manners and even belief systems begin to change, even as certain basic values remain stubbornly resistant and durable. As Victor Turner has noted, this process of negotiation occurs in all societies, at all times, but it appears most clearly when groups are in transition. ${ }^{4}$

The French sociologist/anthropologist Pierre Bourdieu proposes a theory of practice that describes the way people and cultures not only accommodate change, but sponsor it as well. Using a construct that he refers to as the habitus - he describes the "art of living" that children learn in order to achieve practical mastery of the culture; the habitus encompasses a set of principles that guide behavior, but that nevertheless allows a certain freedom to put them into practice. From the habitus - which includes gender roles, eating habits, family morality, taboos and tastes - emerges a repertoire of responses that generally "work," as well as what he calls the "art of regulated improvisation which defines excellence." 5

One notes the introduction of aesthetic judgment in the term "excellence" as it relates to the perception of distinctiveness, creativity, or "newness", which people asses, and then either accept or reject as part of an emerging collective understanding. With an image that conveys both the force of cultural inertia and the potential for changing course, Bourdieu cites Nicolai Hartmann's example of the verbal joust: "Endlessly overtaken by his own words, with which he maintains a relation of "carry and be carried,"..the discourse [of the virtuoso] continuously feeds off itself like a train bringing along its own rails." Although Bourdieu does not use the word, the process he describes as 'regulated improvisation' also describes poetics - the act of making, remaking, and making new.

\section{COLONIA BUILDERS AND MAKING OF PLACE}

This concept of "practice," then, becomes a useful way of understanding the quite dramatic changes in housing that are taking place in the colonias - changes that are instigated by people who have grown up in houses and settings quite different from the ones they are now constructing for themselves. The majority of the people who live and build in the colonias around El Paso grew up in Mexico and, for the most part, lived in traditional Mexican houses - one- or two- room adobe houses with flat roofs. Since the builders' formative experiences of family and social life occurred in vernacular adobe houses, it would appear inconceivable, on the face of it, that such

The adobe walls, flat tin or mud roofs, walled patios and precincts, form the basis for indigenous Mexican housing and an embedded piece of their reality. Having examined these new houses in some detail, I would contend that indeed many of the attributes of traditional houses do reappear often transformed, but nonetheless "durably installed," as the Bourdieu would say - within the new formal language. The colonia builders have neither totally abandoned their formative culture nor totally embraced the ideas and artifacts of their adopted one. The problem becomes to identify the ways in which the traditional patterns have merged with, been disguised by or slipped behind the newer ideas about house form.

\section{DOS AGUAS}

The houses in the colonias, in spite of their engaging idiosyncrasies, range across a surprisingly small number of identifiable types. The colonia houses contain many fascinating transformations of traditional Mexican typologies more than can be discussed adequately in this paper - so I will concentrate on one of the most overt significations, the gabled roof, called "dos aguas" in Spanish.

The term, "dos aguas" translates as "two waters" - a reference to the roof's ability to shed water to both sides rather than collect it on top. Although the usage is common in Mexico, in the borderlands the words resonate beyond the simply functional distinctions; they become tangled in a metaphoric web of meaning that forms a part of the builders' project to construct, not just shelter, but also a reality, a world. Two waters: In the borderlands, the words resonate across a river that also forms a national boundary and flows with water that is existentially different depending on which shore it washes. Such a useful metaphor for describing the implications for personal and cultural identity, future prospects and history, depending on whether you stand on the north bank or the south.

\section{CULTURAL TENSIONS}

Thus preserving the "old forms" appears to be much less to the point than negotiating the more subtle and deeper connections that underlie the new forms and figures that the colonia builders choose to employ. They "study" American culture through their contact with Americans, but most carefully through the miasma of popular culture that they absorb through television, movies and print media. They work in and travel through established neighborhoods of the city, watch the experiments of their neighbors, and decide individually and collectively - on the most appropriate form for their houses.

According to the colonia builders, the pitched roof typifies an American house; the flat roof a Mexican one. They also generally agree that American families are distant, cold, undisciplined; Mexican families are warm, together, respectful. The description of proper family remained remarkably consistent across a spectrum of colonia residents, and there was even more consensus on the proper configuration of the house. The roof form, more than any other aspect, appeared to be identified with a "proper" house. 
The front gabled house has been repeated endlessly across the landscape of drawings by American school children. Thus the colonia builders' presentation of this same image, with its gabled roof, the centered door and two flanking windows becomes a kind of mask that presents both an overt allegiance to Americanness, but also a subtle transfiguration of Mexicanidad that lurks just below the surface. The preponderance of this form undoubtedly indicates its usefulness in signaling this dual meaning, "We are proper Americans; we are a proper Mexican family."

\section{SYMMETRY, FRONT AND CENTER}

The front-facing gable also provides a formal symmetry in the composition of its front facade. Since bilateral symmetry relates very directly to the human figure, its use permits a symbolic embodiment of self, especially in tripartite symmetry that abstracts facial features - two eyes and the forehead, or two eyes and the mouth. Henry Glassie, the renowned scholar of vernacular and folk culture, speaks of the vernacular artisan's "drive to frontality and symmetry." He goes on to argue that symmetry is so firmly embedded in our way of considering problems, that the solution almost inevitably arrives in a symmetrical form, even if the designer uses entirely separate explanations. The colonistas often cited simple function as the rational for the roof, but this glosses over the more ambiguous and unconscious feelings of "correctness" that undoubtedly enter in.

Thus the symmetry of the gable becomes a kind of rhetorical device that establishes the "front" that forcefully demarcates the line between public presentation and private life. People often described the differences between American and Mexican culture in terms of the superiority of the Mexican family. My informants responded to the query about a father's role with answers couched in quite similar language: "The father's role was to "provide all that's necessary; to feed them, to clothe them, to get them a house." Or: "The father is the principle head of the family and gives it support. He directs and guides the kids and sets an example...." This became almost a litany describing the configuration of the proper family, an idealized conception of the patriarch that has structured Mexican families for generations.

It does not require a great deductive leap to make the connection between the two conditions: the ideal structure of the family and the rhetorical structure of the house. The desire to preserve the traditional family finds a forceful representation in the formal figure of the gable, capitalizing on the clarity, the symmetry and the stability of the form. The gabled roof, presented frontally, can be equated with the stability of the hierarchical structure of the family, and the contrast between the flat and the pitched roof runs much deeper than a mere stylistic divergence. As one woman stated: "[M]ost people have the roof like that [with the gable to the front] and I like it. It is more beautiful, the form is better looking. When the peak is to the side, it looks like the house is falling down."

The facade, then, is the male principle: it orders; it provides a barrier between the family and the world, placing them symbolically under his protection. Taking the most basic opposition, male-female, we note that the male principle of paterfamilias, traditionally presented itself in the male's total control of public space. Men left the security of the house traveled "abroad" through the dangers of street and square, confronting a world of commerce and competition. He left behind the enclosed, and hidden world of women and children, safe behind the walls - walls that became the embodied presence of his protection, his shielding - and restricting - body placed between them and the "aires" of the street. In the new reality, the male principle "faces" the street even more squarely, reinforced by the bilateral symmetry that dominates the colonia house formation.

The female principle emerges on the other side - el otro lado being also the phrase used in Mexico to speak of the United States - and it contains both the promise of opportunity, but also the danger, the contamination of a more metaphoric use. When one crosses to the other side (into the hidden, mysterious, and perhaps damned) one can never go back. The engendering potential is matched by its dangerous, transforming capacity. The presentation of women, then, appears in less iconographic ways, since traditionally their space has been "hidden" behind the male image anyway. Thus the house behind the facade, the enfolding rooms, become a woman's embrace; it is no accident that the Spanish word for married, "casado" also translates as "housed." Thus behind the walls dwell more and greater opportunities for change, since to all appearances nothing has changed. And one must note, the interior of a colonia house is often unrelated to its exterior presentation, supporting a dichotomy of meaning and usage between the two. As one informant, explained with a shrug, "It's her house."

\section{CENTRAL HALLS AND SYMMETRY}

One of the notable changes that takes place between the houses of their childhood and the houses the colonia residents build is the inclusion of a hallway. Partly because of the additive tradition, and partly because of the work and expense required to build one, the common folk houses of Mexico do not often include a pasillo, or passageway. The hallway thus becomes an important mark of distinction - of the owners' rising prosperity and concomitant change in class, as well as their reorientation toward new cultural models. But like the dos aguas roof form, the hallway provides multiple readings. On the one hand, it reinforces the centrality, the formality and the propriety of the symmetrical and focused facade. On the other, it provides a simple expression of the separation between public and private, as well as the separation of circulation spaces from the individual rooms - neither of which distinctions are free of their own cultural assumptions.

While we often take hallways for granted, they and the 
individual rooms to which they lead reflect a division of family life into individual cells that honor privacy and individual space above the inclusive gathering of the family. The designation of specific rooms for a particular function mirrors to some degree the complexity of modern urban life, and frankly, the material resources to construct such specialized spaces. Thus, like the facade, the hallway is a mixed metaphor, disguising traditional attitudes with modern rational planning, and overlaying new cultural aspirations upon the order and stability of traditional forms.

Nevertheless, the process is not perfect; the negotiations between known building techniques and new ones sometimes break down. Working from the habitus - in other words, following guidelines rather than delimiting plans the houses, when finished, sometimes end up with the gable toward the side; a long hallway runs the length of the house following the ridgeline of the roof, although still separating the parlor and kitchen at the front from the bedrooms and bathroom at the back. As one of these owners stated, "It is a mistake, I would prefer to have the main gable facing forward with the door right in the middle" - the classic colonia house form. They have since corrected the error by adding a large, gabled porch that dominates the front facade, even though the main axis still runs side to side instead of aligning with a central entry door.

\section{HIERARCHY/HETERARCHY}

A final contradiction that seems to be imbedded in the gabled roof might be called the heterarchy-hierarchy couple. The hierarchy of a Mexican-American family has been challenged by the looser, more ambiguous, and changeable mores that govern Anglo family life, social relations, and especially child rearing. The words "respect" and "freedom" seemed to be emblematic of the different cultural attitudes, and people used them both, sometimes with regret, sometimes with approval.

Kids are so different now; I never talked back to my parents, and my kids do. If we try to discipline our kids, then the kids can just call the cops and have us taken to jail. That's the way it is here.

I heard this apocryphal story more than once during my interviews. It appeared to be one of those "urban myths" that people use to cover the uneasiness they feel about the new freedom that they must extend to their Americanized kids. The use of the word freedom appears to connote a lessening of parental authority, as well as the loss of collective Mexican traditions, the ballast of history and culture.

Respeto - the deference that is due older people, but especially due to one's parents and older relatives - encapsulates this sense of dignity that comes with traditional values. "The thing we want our kids to maintain is the respect: when one sees an older person, one should say, 'Okay, I will do what he says; follow, because he is older."' They noted that in Mexico, people of the older generation almost always use the formal Usted when addressing an older person, even their own parents. In contrast, their own kids refer to almost everyone ast $u$, even their grandparents - the same people whom they themselves were still addressing as Usted.

Thus the hierarchy of traditional culture confronts the heterarchy of post-modern times, American style. Heterarchy, as used here, refers to the collage of competing value systems and the diversity that we extol but find difficult to resolve within a coherent, overarching philosophy. Heterarchy implies a repetitive, looping movement that incorporates objects, images and ideas that then take their meaning from the sometimes random, sometimes intentional juxtapositions that result. The shifting ground as we move between places, people and politics gives precious little guidance even for those of us who are most accustomed to its vagaries. For people moving from a deeply embedded hierarchical worldview, the possibilities, and dangers, must appear limitless.

Colonia houses, with their dos aguas roofs, present a material representation of the layers of culture that exist in all arenas of modern society. Most folk art, craft traditions, food, marriage and family structures occur at a localized, even familial, level of cultural production. At a certain distance from this, the artifacts of popular culture appear, especially those that are carried and sometimes even created by the media: movies, music, fads and fashions, books and name brands. Finally, the elite or intellectual work of culture attempts to supersede, criticize, challenge and even change the course of the broad mass of culture: through museums, "legitimate" theatre, galleries, as well as art-house films, counterculture fashion, academics and activists. ${ }^{8}$

The colonia houses reflect this set of intersecting spheres in a kind of microcosm. From tradition they pull their understanding of family, their love of fiestas, their preferences for the food their mothers made; from popular culture they absorb widely held attitudes about lifestyles, and fashion; and with a capacity for alienation and criticism that we often reserve to ourselves, they turn a cool appraising gaze upon the social and cultural order, even as they struggle to construct a firm foundation for their lives within it.

\section{CONCLUSION:}

\section{TOWARD A SOCIAL POETICS OF HOUSING}

The colonias provide graphic evidence of the process of "cultural construction" as they move away from the traditional, and perhaps no longer useful, forms of housing and create the neo-vernacular houses more relevant to their lives. The notion of society as constructed by its participants, moreover, de-emphasizes the functional explanations that have dominated both anthropological and architectural analyses of housing. This paper argues, however, that our awareness of poetics as a mode of signification also permits a means of analysis that deepens our understanding of a complex and multifaceted phenomenon. 
We see that the colonia houses present a coherent set of meanings that have emerged from the process of negotiation on the part of people moving between cultures. These meanings reflect the earliest knowing contained in the habitus of infancy, filter through the exposure to the ideology of school and mass media, and finally incorporate references to a projected and desired future. The signification that people choose as appropriate for their houses are ones that allow these various levels of meaning to collage, to slip behind each other within the figural presentation. Nevertheless, the very complexity of this process indicates that a serious investigation must use methods that incorporate the fuzzy logic of mythic and poetic expression.

We should note of the wide variety of poetic renderings that the colonia builders give to the house form, but pay even closer attention the underlying commonality that a culturally shared habitus predicts. Thus the mere aping of a traditional form not only risks debasing that formal language, but also misses the opportunity to satisfy a more deeply felt need for a poetic rendering that speaks both to traditional structures and modern aspirations. This process of cultural adaptation - and the need for an appropriately poetic expression-speaks to the issue of change and identity that characterize our mobile and ever-changing society as well. If we can better understand the complex and subtle collage of meaning and form, we will ourselves be better able to create appropriate interventions in the urban fabric, provide more appropriate forms of shelter and their attendant spaces, and thus ensure not only formal delight, but meaningful patterns as well.

\section{NOTES}

- 1 Websters International Collegiate Dictionary

${ }^{2}$ Mary Douglas, Rules \& Meanings: The Anthropology of Everyday Knowledge, Ed, Mary Douglas, New York: Penguin Books, 1973.

${ }^{3}$ Michael Herzfeld, The Poetics of Manhood: Contest and ldentity in a Cretan Mountain Village, New Jersey: Princeton University Press, 1985.

4 Victor Turner, Dramas, Fields, and Metaphors, Symbolic Action in Human Society, Ithaca and London: Cornell University Press, 1974.

${ }^{5}$ Pierre Bourdieu,Outline of a Theory of Practice, Cambridge: Cambridge University Press, 1972.

${ }^{6}$ Bourdieu, p. 35.

7 Glassie, Henry M., "Folk Art" in Thomas J. Schlereth, Material Culture Studies in America, Nashville: The American Association for State and Local History, 1982.

${ }^{8}$ Henry Glassie. p 130. 